\title{
DAS ENTRANHAS DA MEMÓRIA E DOS CLICHÊS NA REVOLUÇÃO ERÓTICA DE Almodóvar
} João Barreto da Fonseca*

(D) https://orcid.org/0000-0003-0425-7666

Kãtia Hallak Lombardi**

(iD) https://orcid.org/0000-0002-8293-8494

\section{Vanessa Maia Barbosa de Paiva***}

(iD) https://orcid.org/0000-0002-8441-0378

Como citar este artigo: FONSECA, J. B.; LOMBARDI, K. H.; PAIVA, V. M. B. de. Das entranhas da memória e dos clichês na revolução erótica de Almodóvar. Todas as Letras - Revista de Língua e Literatura, São Paulo, v. 22, n. 3, p. 1-14, set./dez. 2020. DOI 10.5935/1980-6914/eLETDO2013619

Submissão: julho de 2020. Aceite: setembro de 2020.

Resumo: Nos filmes do cineasta espanhol Pedro Almodóvar, há a convicção de que a manutenção de uma sociedade requer alguma manobra condenável. É o que pretende mostrar a novela-folhetim Fogo nas entranhas, de 1981. Um modo de vida que se alimenta da energia vital, do sexo reprimido dos seus personagens, e que promove a criação de eventos que não se localizam na memória, um tipo de violência que tradicionalmente não está no campo da experiência feminina: a violência sexual da mulher contra o homem.

Palavras-chave: Almodóvar. Folhetim. Memória. Repressão. Erotismo. 


\section{A POÇão máGica da transGressão}

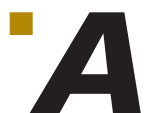

epígrafe da novela-folhetim de 1981, Fogo nas entranhas (2000), de Pedro Almodóvar (1949-), vem de um provérbio chinês: "o demônio caminha em linha reta". E já traz a singularidade de atribuir ao demônio o caminho da retidão. Estão instalados uma novidade e um projeto: os personagens vão fugir da retidão para escapar do diabo, que, na tradição chinesa, apresenta valores distintos dos do catolicismo espanhol. Para abrir os caminhos tortuosos, os personagens entram em contato com uma poção mágica, inserida por meio de absorventes higiênicos, o que muda o rumo dos acontecimentos e rompe a frágil estabilidade na qual estavam baseados os valores de uma sociedade.

Um começo completamente desorganizado joga o leitor dentro da estranheza de ler Almodóvar. Uma mulher em crise por ter 43 anos, uma anciã virgem de 70 anos, que acha que os homens a assediam, uma ex-freira, um senhor loucamente excitado devido à dieta sexual imposta por sua mulher. Todos conversam frivolidades. Esses personagens vão aparecer mais adiante e a dispersão inicial tem a intenção de mostrar que os eventos mais fantásticos acontecem em dias comuns.

Fogo nas entranhas (2000) é uma absurda história de vingança. Após ser abandonado por cinco mulheres, um chinês, radicado na Espanha, dono de uma fábrica de absorventes higiênicos, revolve se matar e deixar uma grande fortuna para as cinco mulheres que o abandonaram. Mas há uma exigência. No dia de seu sepultamento, elas deveriam comparecer e usar sua última invenção, um absorvente higiênico novo e sofisticado. Para ressaltar sua imagem de homem altruísta e amante das mulheres, o chinês ainda oferece uma semana de absorventes grátis para todas as mulheres de Madri. Os absorventes estão contaminados com uma substância que transforma as mulheres em sedentas por sexo, levando seus parceiros à morte pela exaustão.

Para Almodóvar, o mundo é sustentado por sacrifícios pessoais e a razão castiga o corpo, mantendo-o sob controle. Quem sabe usar doses corretas de comedimento e de temperança, reservando para os desvios um local socialmente aceitável, é premiado no jogo da recompensa e da punição - aqueles que têm "soberania sobre si mesmos" (FOUCAULT, 1998, p. 30).

Com o enlouquecimento coletivo, em Fogo nas entranhas (2000), Almodóvar coloca em xeque o longo trabalho de aprendizagem das regras, da assimilação de condutas e princípios, que objetivam a renúncia, a moderação, o ideal da fidelidade e da castidade. Almodóvar apaga a memória relativa à prescrição para fazer sobrar a força e o desejo. Se "a memória se comunica com a percepção e tem função utilitária” (BERGSON, 1999, p. 77), os personagens, sem os recursos de suas lembranças repressivas, sem a presença do interdito, agem de forma mais imediata e se entregam ao mundo "selvagem". A memória, em Bergson (1999), forma o esquema sensório-motor, que responde pelas habilidades de reconhecimento que permitem, pelo treinamento, alcançar a eficiência. Por outro lado, os condicionamentos produzem uma névoa sob as ações não repetitivas e criativas. Tensionando esse pensamento, Foucault (1998, p. 31) argumenta que a virtude, como um tipo de treinamento social, no qual se ancoram nossos processos de subjetivação, "é um luxo e tem muito menor importância que o funcionamento dos instintos inconscientes". Assim, a virtude "ainda é menor 
que a imprudência temerária de se arremessar sobre o inimigo e que a espontaneidade entusiasta da cólera, do amor, do respeito, da gratidão e da vingança" (FOUCAULT, 1998, p. 31).

Os feitos extraordinários, como realizações de fantasias sexuais reprimidas, podem tanto descambar para o sublime como para o grotesco. Essa ambivalência produz a experimentação de um estado duvidoso, que não permite aos personagens gozarem de estabilidade: por não existir um modo de viver sublime ou grotesco per si, essencializado. Os acontecimentos dependem sempre de uma interpretação, de uma crítica, sobre o conjunto de forças que combinam o pessoal com o social. Os monstros são sempre os outros e ajudam a manter uma imagem estável de si mesmo. O monstro atrai como um ponto de fuga ou como um bode expiatório (como quando se ri de uma piada grotesca, por temer ser objeto dela). Os monstros são imagens. Para Bhabha (1998, p. 86), “a imagem é apenas e sempre um acessório da autoridade e da identidade; ela não deve ser lida mimeticamente como aparência da realidade". Para o crítico, as imagens são signos de sua ausência ou perda, e estão sempre metonimicamente apontando para um além.

Em Fogo nas entranhas (2000), o monstruoso e o grotesco surgem como estratégia de transgressão das ilusões repressivas e dos usos políticos da razão e do abuso da beleza. Tudo soa como um tipo de racionalismo irracional, um tipo de lógica radical que não quer explicar, nem justificar. Machado (2009, p. 211) explica que, para Deleuze, a linguagem é uma condição da criação de um saber sobre a vida, um tipo de saber que escapa ao senso comum, "criando novas possibilidades vitais, novas formas de existência. Não qualquer tipo de vida, mas uma "vida desconhecida"' (MACHADO, 2009, p. 211). Uma vida constituída por forças, atravessamentos, combinações inusitadas, novas composições, intensidade, singularidades, virtualidades.

Para conferir leveza a eventos esdrúxulos, o escritor recobre a trama de clichês. Sob a chancela do humor, evoca-se um tipo de memória saturada, de imagem consagrada pelo hábito que, embora não faça uma ligação necessária com o mundo exterior, funciona como um anestésico para a execução das atividades cotidianas e a aceitação das aventuras mais extraordinárias.

\section{NÃo VEJO A HORA dE FAZER 100 ANOS}

No início da trama, os personagens exibem seus recalques e frustrações como se tivessem perdido o tempo de dar uma resposta aos agravos da vida. Para a personagem Eulália, "nem o dinheiro e nem o marido a faziam feliz" (ALMODÓVAR, 2000, p. 15). Já Isidra, uma virgem de 70 anos, repetia: "Não vejo a hora de fazer 100 anos, para ver se os homens me deixam em paz" (ALMODÓVAR, 2000, p. 18). Raimunda diz sobre o marido: "Ele trabalhava no Conselho Superior de Químicos, mas no fundo é um grande poeta" (ALMODÓVAR, 2000, p. 25). O ressentimento, segundo Maria Rita Kehl (2015, p. 20), é uma reação adiada que se impediu por conta própria. "O ressentido seria aquele que renuncia seu desejo em nome da submissão do outro. Mas depois vem cobrar, insistentemente, pelo desejo negado" (KEHL, 2015, p. 24). Para Nietzsche (1992, p. 60), do ressentimento saem, sob o nome de justiça, ações "em proveito do ódio, da inveja, do desrespeito, do rancor, da vingança". Por isso, Nietzsche considera o ressentido um tipo de indivíduo que contraiu uma doença de memória, 
agravada pela recusa da vida presente e pela impossibilidade de se viver para trás. Em Almodóvar (2000), o passado é ruim até quando é bom. Quando ruim, é nomeado de remorso. Quando bom, tem o nome de nostalgia. Em ambos os casos, é um tipo de vínculo que resulta num julgamento da memória. E, de qualquer forma, é um empecilho da vida no presente.

A memória do sofrimento e da injustiça alimenta o ressentimento quando sua evocação serve para manter as antigas vítimas na mesma posição que ocuparam no passado, colhendo os ganhos secundários da autopiedade e da má consciência (KEHL, 2015, p. 310).

O ressentimento é fortemente literário, responsável por tensões nas narrativas. A literatura está repleta de personagens que imaginaram outra vida, mas que, por forças diversas, adiaram a vingança, mas se mantiveram sonhando, imaginando, remoendo, tramando e expondo sentimentos que são autorizados mediante um código moral que valoriza a maldade e a covardia.

A opressão se realiza no espaço da casa, enquanto a rua se apresenta como local de possibilidade, de combinações inusitadas e de acasos. Os lares estão marcados por uma arquitetura rígida que condiciona os gestos dos corpos. Também é na casa, devido a sua característica de local de controle, que se permite organizar o discurso de ressentimento. "Isto resulta em redesenhar o espaço doméstico como espaço das modernas técnicas normalizantes, pastoralizantes e individualizantes do poder e da polícia modernos: o pessoal é o político, o mundo-na-casa" (BHABHA, 1998, p. 32).

\section{SEXO: ÓPIO DO CORPO}

O livro ganha outro ritmo a partir do momento em que a rua passa a ser o cenário e os personagens trocam a verborragia erótico-depressiva pelo mundo da ação, permitindo substituir a memória-clichê (dos modelos cognitivos que impedem de ver o mundo de fora) por novas imagens. Almodóvar antecipa o trabalho de Bhabha (1998, p. 34, grifos do autor): "Como criaturas literárias [...], devemos nos preocupar com a ação humana e do mundo social como um momento em que algo está fora de controle, mas não fora da possibilidade de organização". A organização se dá pela narrativa, cuja perspectiva é apresentar a loucura como uma virtualização dos momentos atuais de normalidade. E também mostrar o que ocorre quando essa situação é invertida. "A ideia de uma substituição do real pelo virtual se reporta a uma dicotomia exportada das categorias de representação: imagem no lugar do objeto, imaginário no lugar do real" (PARENTE, 1999, p. 43). Um universo de possibilidades está contido nos personagens pela frustração e pelo ressentimento - como uma planta que não vinga (vingança como uma possibilidade da realização do ressentido).

A artista alemã Monika Fleishman fez um experimento que, ressalvadas as diferenças, tem um objetivo parecido com o de Almodóvar. André Parente (1999, p. 40) conta que Fleishman confrontou a Berlim atual com a antiga cidade do muro para constatar que as pessoas, na atualidade, ainda veem um muro que não mais existe. A intenção é vencer o clichê, que é um tipo de memória interna, que não permite ver o mundo externo como ele é. "A neurose é constituída de imagens mentais petrificadas (espaço de interioridade) ou condicionamentos sensório-motores" (PARENTE, 1999, p. 39), que são empecilhos para as imagens que vêm de fora, quando a situação já se modificou. 
Em Almodóvar (2000), um mundo de desejo só é possivel como complementar a este mundo, que só é acessado via aditivos (no caso, o absorvente higiênico) que justifiquem estados alterados de consciência e de motivações corporais. Os personagens não negligenciam o conjunto de valores apresentados pela sociedade em questão, caso contrário não precisariam de aditivos que proporcionassem a transgressão. Na verdade, a transgressão é um complemento do interdito, mas aqui pode ser entendida também como encantamento.

Na novela-folhetim (2000), as mulheres, "contaminadas", andam como vampiras pelas ruas de Madri: querem sangue e levam os homens a sangramentos mortais. Não basta seduzir, elas querem realizar. Sexo não basta, tudo deve ser público. A crítica só funciona se tudo ficar explícito, a notar que uma das formas de condenação do sexo na Grécia antiga, segundo Foucault (1998), era recomendá-lo para a noite, incluindo na "necessidade" um aspecto racional para o seu adiamento. Para exemplificar a ruptura dessa proibição, ele lembra Diógenes Laércio (180 d.C.-240 d.C.), que tinha uma crítica peculiar a essa não publicidade. Ele tinha o costume de tudo fazer em público: "se não há mal em comer, também não há mal em comer em público" (FOUCAULT, 1998, p. 52).

Almodóvar (2000) adota essa lógica, que é contrária à prescrição corrente. O que foi socialmente reprimido ganha a luz do dia, para recriar um mundo feminino que, para o autor, vive na imaginação. O gênero, nesse sentido, performatiza, ou, ainda, produz práticas comportamentais e estéticas que são barreiras e empecilhos para uma vida plena. Os acontecimentos inconcebíveis são movimentos descondicionantes. O cotidiano, assim, é uma revolução sexual.

Num momento, sob a influência dos absorventes, a personagem Mara vê dois homens da limpeza pública regando a rua. "Mara aproximou-se do jorro da mangueira, levantou o vestido, abriu as pernas, entre gritos de gozo, preparou-se para receber o forte jorro de água na xoxota" (ALMODÓVAR, 2000, p. 73). Tudo no livro parte do particular para o coletivo, como um tipo de compartilhamento de ideias submersas: "As outras (transeuntes) ficaram com inveja e imediatamente se juntaram a Mara” (ALMODÓVAR, 2000, p. 73). A revolução é produto de singularidades. De acordo com Gil (2000, p. 176), "a força e a saúde de uma cultura medem-se pela sua aptidão a transformar-se; pela sua plasticidade, pela sua apetência em devir, evoluir [...]”. Lembramos também Guattari (2012, p. 85):

[...] produzir uma nova música, um novo tipo de amor, uma relação inédita com o social, com a animalidade: é gerar uma nova composição ontológica corretiva a uma nova tomada de conhecimento sem mediação, através de uma aglomeração prática de subjetividade.

O sexo é o ópio do corpo na medida em que a temperança e o comedimento são moedas correntes da repressão sexual. O domínio sobre o corpo e todo tipo de investimento pelo poder, pelos anos a fio de treinamento, no qual estão inseridos todos os processos de docilidade dos corpos femininos, agora estão atenuados nesta novela-manifesto. Ou ainda: as características não temperantes do sexo não comedido tornam-se não só evidentes, mas desejadas, uma vez que não podem ser evitadas devido a um tipo de "contaminação" por substâncias cujos efeitos são a excitação e a realização do prazer.

Podemos também pensar em um tipo de prazer ao qual se entregam por falta de saúde, já que as mulheres são estimuladas por drogas. Mas adestrar o corpo como 
investimento do poder, talvez como saída, faça emergir "inevitavelmente a reivindicação do próprio corpo contra o poder, a saúde contra a economia, o prazer contra as normas morais da sexualidade, do casamento, do pudor" (FOUCAULT, 1984, p. 146). Nesse caso, o manifesto é um tipo de contratexto, já que a fenomenologia da monstruosidade é acompanhada e reforçada historicamente por textos: "de Santo Agostinho a Descartes, da viagem fictícia de Mandeville aos contos populares" (GIL, 2000, p. 174).

O estilo folhetim porno-soft permite ao escritor experimentar os enredos mais fascinantes, recheados de reviravoltas, de mudanças bruscas de temperamento dos personagens, de intervenção da providência divina e de desprezo pela ciência. A apresentação do chinês Chu Ming Ho é modelar. Almodóvar descreve que, nos anos 1950, Chu Ming Ho chegou à Espanha, depois de mortes na família:

Seu pai havia sido picado por uma serpente, sua mulher fora arrastada por uma inundação e seu filho, atacado por um tigre. Mas não foi por causa disso que ele saiu de Singapura. Ming odiava a Lua e a mulher chinesa se parece com a lua (ALMODÓVAR, 2000, p. 49).

Fogo nas entranhas (2000) exibe a liberdade inspiradora dos folhetins para abordar a temática da violência da mulher contra o homem, especificamente o estupro. Sim, há uma inversão na trama. Pura imaginação, fora da experiência. Essa liberdade é um lembrete de que a organização social é sempre passível de questionamentos. A liberdade é inescapavelmente agonística, porque está condicionada ao estranhamento. "Ela implica um ceticismo para com as categorias fundacionais ou expressivas e uma reflexão sobre a instituição e a negociação da autoridade" (DONALD, 2000, p. 83). Negociação também é a palavra que Bhabha (1998, p. 51) utiliza para se referir à "articulação de elementos antagônicos ou contraditores", para além de uma dialética teleológica.

Para Despentes (2016), as categorias fundacionais da mística feminina incluem a observação de que as mulheres alcançaram todos os postos da política, da economia e dos esportes, inclusive o futebol, mas o estupro é exclusividade do masculino. "Não a guerra, a caça, o desejo cru, a violência ou a barbárie, mas justamente o estupro, essa coisa da qual - até o momento - as mulheres nunca se apropriaram" (DESPENTES, 2016, p. 42). E como, no livro de Almodóvar, não há argumentos tais como "os homens facilitam", "usam roupa curta", "se não fossem os garotos de programa haveria mais estupros", o leitor é pressionado a pensar a violência fora dos parâmetros existentes ou ainda é obrigado a relativizar pretextos utilizados para explicar a violência contra a mulher. Almodóvar não produz uma oposição entre o masculino e o feminino. Sua intenção não é transformar a mulher em um homem, nem suscitar as discussões já congestionadas sobre o assunto. A transformação das personagens é a descoberta de um devir, o escape de uma forma dominante. "Devir não é imitar e nem fazer como se, nem se conformar a um modelo [...]. Não há um termo ao qual se parta, nem ao qual se chegue, ou ao qual se deva chegar" (DELEUZE; PARNET, 1998, p. 8).

Conforme Despentes (2016, p. 28), o feminino é lugar da humilhação, do medo e do estrangeiro. A virilidade masculina seria construída pela desconsideração, pela exclusão do corpo feminino. "Uma empreitada política ancestral, implacável, ensina as mulheres a não se defender" (DESPENTES, 2016, p. 38). Despentes refere-se ao apagamento histórico da memória da mulher guerreira. $\mathrm{E}$ 
também lembra que os homens que vingam suas mulheres violentadas parecem dizer, secretamente, "por que vocês não reagem de forma violenta?"

As mulheres de Chu Ming Ho espelham a descrença em alternativas racionais para soluções de problemas humanos ou representam descrenças em facções e segregações. Elas são propostas da modernidade que não se cumpriram ou efeitos colaterais de momentos históricos. Os personagens de Almodóvar vão muito além de um papel narrativo comum. A intenção é mostrar a produção de subjetividade a partir da luta ideológica (e pela liberdade) de movimentos coletivos.

\section{As cinco mulheres de Chu Ming Ho}

A primeira mulher de Chu Ming Ho, Katy, representa a Guerra Fria. Depois da diminuição de oferta em intrigas internacionais, foi trabalhar como espiã de segunda classe, cuja tarefa era seguir os passos do velho chinês para uma loja concorrente. Acabou morando com o chinês. O folhetim de Almodóvar reserva situações que estão de acordo com o personagem enfocado, sem preocupações com a verossimilhança, bem ao gosto do kitsch espanhol, gênero artístico consagrado, cujas técnicas permitem um acesso atravessado às coisas, ampliando-as, mas sem se aproximar delas. Polimeni (2004, p. 23) afirma que Almodóvar constrói cortinas de fumaça com os exageros: "Um motivo de distração, que o permitia esconder-se, com pudor".

Esse tipo de desatenção calculada funciona para dar consistência ao gênero e permitir voos mirabolantes à narrativa, como a fuga de Katy pelo telhado. A Guerra Fria, com seus saldos terriveis, e a política que lhe deu origem são propositalmente abandonadas, pois basta a dramaticidade piegas para sustentar o clichê, bem representado no chinês acenando um adeus com um sapato que subtraiu da amada no momento de sua fuga pela cobertura em um helicóptero.

A segunda esposa do chinês, Mara, é o cinismo, é a individualidade, a descrença em qualquer relação coletiva. Primeiro ela. Nenhuma proposta de movimento a interessa. O diálogo de sua partida é modelar.

- O que você está fazendo?

- Nada. Estou arrumando minhas coisas, respondeu ela sem interromper o que estava fazendo, e sem dar muita importância ao chinês.

- Você está fugindo?

- Eu? Imagine! Você pensa cada coisa...

E soltou uma risadinha, bancando a ingênua. Sentou-se em cima da mala.

- Vamos, me ajude....

Apanhou as malas e caminhou para a porta.

- Onde é que você está indo, Mara?

- Levar as malas lá para baixo. Volto já.

Ming contemplava estupefato. Não sabia por que, mas o cinismo de Mara o deixa estupefato [...]. Chegou na janela e viu como Mara encontrava o homem que a esperava no automóvel. Colocaram as malas dentro do carro, deram um beijo de língua e desapareceram (ALMODÓVAR, 2000, p. 22-23).

A insignificância do chinês fica patente na conclusão do capítulo: "Pareciam (os amantes) não dar importância para a chuva” (ALMODÓVAR, 2000, p. 22).

O cinismo de Mara não advém somente da desconsideração do outro como um ser vizinho e também não vem apoiado no argumento do distanciamento causado 
pela urbanidade. Sua indiferença é decorrência da perda de um eixo central. Ela, como as mulheres de Almodóvar nessa trama, perdeu o interesse pelos aspectos tradicionais do feminismo, e esse rompimento favorece a iniciativa, a criatividade. Dessa forma, a indiferença é a via de acesso ao alivio das obrigações.

A adesão instantânea de Lupe, a terceira mulher, ao movimento hippie, coloca em xeque a malícia e a esperteza da contracultura. Lupe trocou o chinês para aderir ao movimento hippie. Para começar, um naturalismo débil: "Lupe foi até o parque [...] Era primavera. Os pássaros cantavam pressagiando a chegada do bom tempo. Lupe embriagava-se com o cheiro da natureza" (ALMODÓVAR, 2000 , p. 32). A sequência soa como uma sucessão de quadros, como uma montagem cinematográfica, oferecendo visualidades clichês distintas em cada corte, possibilitando entendimentos complementares ou opostos a partir da justaposição de imagem. Acontece que o primeiro contato de Lupe com o movimento hippie foi intermediado pelos clichês. "É a representação de um tempo que está em outro lugar, uma repetição" (BHABHA, 1998, p. 85).

Em seguida, Lupe ouve a canção no violão:

Gosto de paz/ gosto de amor. /Sou capaz de cheirar uma flor /o trabalho me cansa, / a rotina me deprime, / a cidade me sufoca, / a sociedade me oprime. / Só existe um caminho / pra não estourar: /Viva seu destino /Sem deixar alguém te amarrar (ALMODÓVAR, 2000, p. 33).

É claro que Lupe, uma mulher simples, fica encantada com o lado ingênuo da contracultura. "Decoraram sua cabeça com flores. Um hippie beijou-a, outro também. Um terceiro deitou-a no chão, levantou sua saia e começou a lamber sua xoxota com naturalidade" (ALMODÓVAR, 2000, p. 33-34). Lupe partiu com a roupa do corpo. Com o retorno de Lupe para Madri, após a morte do chinês, Almodóvar parece querer mostrar que as propostas coletivas se esbarraram nas pequenas viabilidades, nas impossibilidades de combate tanto à repressão interna, individual, quanto às externas, sociais, politicas e culturais. O escritor decompõe os centros irradiadores e coletivos de liberdade tendo como base a experiência cotidiana - a totalidade só pode ser entendida de modo parcial.

Diana, a quarta mulher do chinês, tinha vivido num orfanato, "odiava os ricos, as freiras e tudo que tivesse cheiro de legalidade". Trocou um cargo de chefia na empresa de Ming para se juntar às feministas, mas acabou trabalhando, por ironia, na seção de objetos eróticos na sex shop das feministas. De militante feminista à vendedora de sex shop, Diana perde o sentimento de grandeza. Diana, como todas as mulheres da trama, luta contra os traços tradicionais do feminino e todos os seus ódios são, na verdade, princípios.

Raimunda, a quinta mulher, também vem de outra instituição que ensina o comedimento. Como ex-freira, ela é boazinha e, ao largar Chu Ming Ho, casa com o homem que julga ideal para com ele viver o resto de sua vida. Ela é puro ideal e, mesmo conscientemente distante de seu passado católico, é uma programação cristã. Este é o seu modelo de pureza. Das mulheres de Ming, Raimunda é a única que não é contaminada, porque não aceita usar o absorvente na cerimônia enterro de despedida, da qual não participou. Ela executa uma memória implantada. Seu passado é outro. Ela tem bases na austeridade, portanto deve provar que o ato sexual não ocorre à revelia da vontade, porque aprendeu que "a temperança sexual é um exercício de liberdade sobre si" (FOUCAULT, 1998, p. 85). 


\section{VINGANÇA FEMININA}

Nas tramas do cineasta, há a edificação de um mundo paralelo (virtual que, às vezes, se atualiza) em que as leis que imperam na civilização são temporariamente suspensas e dão lugar a tudo que a cultura batizou de mau ou ruim, mas que na ótica do escritor-roteirista responde pelo prazer: "as tentações são simplesmente aumentadas pela frustração constante, ao passo que a sua satisfação ocasional as faz diminuir, ao menos por algum tempo" (FREUD, 1997, p. 87). Essa argumentação se complementa com o pensamento de que o unheimliche (o estranho-familiar) é o nome para tudo que deveria estar secreto, mas que veio à luz (FREUD, 1988). Ou ainda: são os futuros, possíveis mas sufocados, aos quais os personagens se apegam, por fantasia, e os nutrem pela ilusão de uma vontade livre. Comentando o estranho de Freud, Butler (2017, p. 91) diz que o modo corriqueiro dos significados sexuais é constituído pela exceção: "É somente a partir de uma posição conscientemente desnaturalizada que podemos ver como a aparência de naturalidade é ela mesma construída".

Os momentos clichês não são necessariamente falta de seriedade, mas uma tentativa de abordar a questão feminista a partir de um ângulo menos congestionado pelo hábito e com a liberdade atribuída à ficção. Em certos momentos, as personagens apresentam discursos bastante consagrados pelo feminismo: "Mulheres! Estamos, há séculos, sendo exploradas pelos homens [...] Só controlamos as máquinas de lavar roupa, as máquinas de lavar louça, os liquidificadores, as secadoras, as frigideiras, as geladeiras, os exaustores" (ALMODÓVAR, 2000, p. 41). As palavras da militante ficcional avivam a memória das teorias feministas de Betty Friedan (1971), para quem a mulher, nos Estados Unidos, se tornou um alvo da propaganda de eletrodomésticos (que substituiam, terminada a guerra, o material bélico).

O feminismo de Almodóvar difere do de outros escritores homens por um tipo de radicalidade que convém buscar algo fora do campo da experiência e da memória: mulheres no comando da violência sexual e também na violência física não sexual. Mulheres perambulando pelas ruas de Madri em busca de "presas" do sexo masculino. É a imaginação, como algo virtual, que se atualiza no ato da leitura a partir de um tipo de visualização (imagens sem bordas e sem contornos) que só é possível na ficção literária. Almodóvar comenta que os pedidos para transformar Fogo nas entranhas (2000) em um filme foram veementemente negados. Para o diretor, esse nivel de falsidade é permissivel somente na imaginação.

A trama de Almodóvar também não resolve a relação corpo e mente (alma, consciência) que, na tradição filosófica, se inicia com Platão e continua em Descartes, Husserl e Sartre. No entanto, a relação não é mais falocêntrica. A mulher ainda é corpo e também mente. Aliás, muito mais corpo, porque a mente funciona em um momento de desrazão. "Beauvoir propõe que o corpo feminino deve ser a situação e o instrumento da liberdade da mulher, e não uma essência definidora e limitadora", resume Butler (2017, p. 35). A autora ainda conclui: "Resulta que qualquer reprodução acrítica da relação corpo/mente deve ser repensada em termos de hierarquia de gênero [...]" (BUTLER, 2017, p. 36). A liberdade sexual, para Foucault (1998), estaria relacionada à crítica sobre a repressão sexual e também ao discurso sobre a sexualidade. Segundo Chauí (1984, p. 182), isso significa não só a crítica ao conjunto de disciplinas tais como a medicina, a pedagogia, a psiquiatria, a psicanálise, entre outras, "mas também a crítica de 
suas críticas, pois estas permanecem no mesmo campo definido pelas estratégias do discurso da sexualidade". Chauí (1984, p. 182) define a repressão sexual como "um processo de mutilação, desvalorização e controle da sexualidade como pecaminosa, imoral e viciosa".

A vingança feminina em Fogo nas entranhas (2000) difere por não se situar no campo da experiência. Conhecemos exemplos de como se "dobra" uma mulher em Madame Bovary (1856), de Flaubert, em A Mandrágora (1524), de Maquiavel, ou em A megera domada (1594), de Shakespeare. Mas os tempos são outros para Almodóvar. Henri James não chega a tratar de virtualidade em seu romance Retrato de uma senhora (1881). A personagem principal, Isabel Archer, pode escolher entre uma tradição (o casamento e uma vida para o lar) e a ruptura (aventuras, viagens, conforme seu desejo inicial, antes de seu mudar para Londres). São mundos possivveis não apenas na imaginação, mas também na experiência. Cavar uma língua estrangeira dentro da própria língua também é o papel de Ibsen, na peça Casa de bonecas (1879), com um final de pura radicalidade, mas também dentro do campo do possível, assim como As religiosas (1796), de Diderot, que se parecem com as freiras de Decameron (1348), de Boccaccio. Em todas as tramas, há um tipo de negociação em que o elemento masculino exerce um tipo de autoridade. Dostoiévski radicaliza ao não apresentar nenhum tipo de possibilidade ao iniciar o seu Uma criatura dócil (1876), com a protagonista de seu romance morta em cima de uma mesa. Não há nenhum tipo de virtualidade, apenas um passado trilhado em direção à morte. Almodóvar cria um artifício semelhante aos contos de fadas, que conferem às mulheres um poder sobrenatural e, consequentemente, o domínio da narrativa.

Os homens, passivos, são vítimas das mulheres com "fogo nas entranhas" (o similar do "calor na bacurinha" da marchinha de Carnaval, como bem registrou Regina Casé na introdução do livro). Na passividade masculina, há um certo ar de abandono e autodestruição. Gómez e Larrondo não têm relação com outros personagens da trama, são secundários, mas não menos importantes. Eles são apresentados sem nenhuma condescendência. "Eram dois monstrengos", penaliza Almodóvar (2000, p. 35), lançando mão do mito da beleza que gera pressão no universo feminino: "Máximo Gómez tinha cara de queijo redondo [...] Paco Larrondo exibia uma magreza cadavérica que acentuava todos os seus defeitos físicos". Almodóvar é desleixado na descrição desses dois personagens, aplicando sobre eles um tipo de psicanálise rasa para justificar a virgindade de ambos: "Sua abstinência era causada por razões que teriam que ser buscadas na infância quando começaram a se interessar pelo idioma chinês" (ALMODÓVAR, 2000, p. 35).

Paco foi criado por mãe e irmã, especializadas em perversidades cotidianas, repletas de pequenos detalhes sem importância. As duas odiavam o idioma chinês, e Paco tinha por princípio amar tudo que as duas odiavam. Gómez se interessou pelo mandarim para ser original, porque sabia que "nada nele chamava a atenção" (ALMODÓVAR, 2000, p. 437). Os dois se conheceram nas aulas noturnas e conseguiram, ao ficarem mais velhos, tirar algum proveito dessa "excentricidade" traduzindo livros, legendando filmes.

Virgens, os dois são os únicos na trama que podem desvendar o motivo da transformação de mulheres pacatas e reprimidas em vampiras sexuais taradas. Gómez e Larrondo dominam o mandarim e, com o diário do chinês em mãos, eles têm algum tipo de poder, que resolvem não exercer. Ou por outra: exercem o 
poder negando-o, rejeitando traduzir os mistérios do diário para assim manter o privilégio de não mais precisarem se humilhar em investidas amorosas fracassadas, uma vez que, na nova condição, o sexo vem até eles.

\section{A força bRUta de Almodóvar}

Por meio da crítica do comportamento de cada indivíduo de sua trama, Almodóvar tem um objetivo muito maior. Se a vida humana comum sofre a pressão de uma comunidade organizada com suas leis, o escritor pretende dizer que, embora não haja saída em relação a esse sentido de opressão coletiva, é possivel criar brechas através de uma energia particular, de uma força bruta.

Essa mesma força bruta é o estilo do escritor. Algo que se destaca como singularidade, que viola a lei coletiva para relativizar a noção de justiça, de ordem. "Por isso, através de cada combinação frágil é uma potência de vida que se afirma, com uma força, uma obstinação, uma perseverança ímpar no ser" (DELEUZE; PARNET, 1998, p. 11). Talvez essa seja a posição privilegiada do escritor: mostrar que o estatuto legal para o qual todos contribuem com sacrificio está à mercê de sua força bruta, embora dentro de espaços convencionalmente rebeldes. Almodóvar dizia, sobre a direção de seus filmes, "que não dirige quem sabe, mas quem quer" (POLIMENI, 2004, p. 59). Daí fez do erro um tipo de recurso, de trunfo. É como colocar o fracasso nas paradas de sucesso.

É o estilo como memória de si. É pela concentração de características singulares que podemos identificar autores distintos como Almodóvar, Brecht ou Nelson Rodrigues, só para citar alguns. Por um lado, é a prisão, a impossibilidade de ser outro. Por outro, a liberdade: a dissonância, a particularidade, a afirmação da vida. Por essa razão, ler Fogo nas entranhas (2000) é entrar em contato com a singularidade de outras obras do cineasta. Almodóvar, em entrevista cedida a Frederic Strauss (2008, p. 278), diz que o que caracteriza seus personagens é a sua vida pessoal, embora pertença à ficção: "Não é um vínculo direto, evidente, mas profundo". Sexo, droga, humor e melodrama são características das tramas de Almodóvar. Um além disso é simplesmente inimaginável.

Almodóvar também investe contra as máximas do próprio gênero: o melodrama. A paixão é a primeira vítima. Maria Rita Kehl $(2015$, p. 182) ensina que a paixão romântica é representada por aqueles que sofrem, que são puros ou que são inocentes demais para viver neste mundo. Primeiramente, não existe amor romântico em história de Almodóvar e todos os puros e inocentes são corrompidos em seus ideais, tornando-se perversos. O melodrama em Almodóvar é o excesso, o texto de reviravoltas (à moda folhetinesca) e o gosto pelo popular.

O tempo passou e Almodóvar mudou, envelheceu. Como suas histórias são falsas autobiografias, misto de ficção com acontecimentos vividos, o diretor espanhol agora combina o uso de drogas com o de produtos farmacêuticos. Em Dor e glória (2019), para abordar a questão de seu envelhecimento, o diretor parece concentrar todos os temas de filmes anteriores para mostrar como eles se relacionam com a saúde em decréscimo. "[...] os grandes pensadores têm, a um só tempo, uma vida pessoal frágil, uma saúde bastante incerta, ao mesmo tempo que levam a vida ao estado de potência absoluto ou de grande saúde" (DELEUZE; PARNET, 1998, p. 13). Em Almodóvar, uma recombinação interna dos mesmos elementos produz uma série de obras novas e distintas. 
A atriz Regina Casé, no prefácio de Fogo nas entranhas (2000), arrisca análise que pode ser estendida ao conjunto da obra: quase todos os filmes de Pedro Almodóvar são assim: "acontecem logo de cara coisas incríveis e escabrosas... Mas no fim os personagens que atuaram na trama fecham o filme fazendo um café ou conversando amenidades" (ALMODÓVAR, 2000, p. 7-8). E ainda há o vermelho, no figurino, no cenário e no corpo. É o mirabolante, como se nota numa simples sinopse de um de seus clássicos - ganhador de um Oscar de filme estrangeiro -, Tudo sobre minha mãe (1999): freira grávida de travesti soropositivo é socorrida por mulher que teve filho (recentemente morto na trama) da mesma travesti. Esse tipo de ironia folhetinesca, combinada com humor, possui uma graça crítica e funciona como estrutura na obra do cineasta.

No todo ou em parte, o humor e a exceção são estruturais nas tramas de Almodóvar. E, não raramente, o desmascaramento dos recursos empregados soa como gesto autorreflexivo. Qualquer filme, colhido dentro da vasta obra, serve de exemplo: Em Labirinto de paixões (1982), uma psicóloga passa roupa enquanto atende pacientes; em Maus hábitos (1999), freiras preferem ser chamadas de nomes depreciativos como Esterco, Rata de Porão e Perdida, para não esquecerem do "passado pecaminoso". Em Carne trêmula (1998), uma mulher dorme, sem saber, com o rapaz que deixou seu marido paraplégico. Em De Salto alto (1991), uma filha ouve, na cadeia, em um radinho de pilha, a voz de sua mãe cantora, que a abandonou: "se você sentir vontade de chorar, pense em mim". O elegante O matador (1986) poderia servir como ilustração da tese defendida por George Bataille em O erotismo (1957): a fugacidade do orgasmo garante não só a beleza como também a danação das relações sexuais. Nesta história de Almodóvar, o exagero dá conta de mostrar que até o movimento do cosmos é entendido como consequência de uma atividade erótica - ao coincidir as cenas de sexo com eclipses. Em Fale com ela (2003), um enfermeiro mantém uma relação sexual com uma bailarina em coma, resultando numa gravidez que, por sua vez, é responsável por tirar a mulher do coma.

Patty Diphusa (2006), seu outro romance, publicado em 1990, traz crônicas que Almodóvar escreveu ao longo dos anos 1980. É uma escrita com lances autobiográficos. Patty Diphusa é uma ex-atriz pornô que é convidada a relatar suas memórias em uma revista. Ela começa dizendo que aproveitou o melhor da vida: drogas e sexo. No prefácio, Ana Luiza Beraba destaca a declaração do diretor no FestRio, em 1986: "para fazer cinema é importante ser gente da noite, se drogar, se embebedar, cair no mundo". No prólogo, Almodóvar brinca com a originalidade, resumindo: "[...] quanto mais plagiávamos, mais autênticos éramos" (ALMODÓVAR, 2006, p. 11), e também conta que, apesar de ser chamado de Andy Warhol espanhol, era sempre apresentado ao próprio, que fingia não conhecê-lo, por estar mais interessado na amizade das marquesas, para quem tinha a esperança de vender seus quadros. Enfim, a trama parece guiar o leitor para um ambiente hostil, sem grandes esperanças e sem sentido de transcendência.

Patty Diphusa é convidada a escrever suas memórias em uma revista. O próprio convite é autodeboche. O importante é o efeito, a performance.

- Sou o diretor de La Luna, uma revista nova.

- Adoro a sua revista! - respondi com muita intensidade.

- Mas como se ainda não saiu o primeiro número? 
- Não importa. Guando gosto de alguma coisa, gosto logo. - Falei com tanta convicção que ele teve que me bajular um pouco.

- Te admiro muito, Patty. Sua última fotonovela, "Porcas Gêmeas", é uma bênção para o espírito e uma pérola de mau gosto. Por que você não escreve para nós? $O$ país mudou muito nos últimos dias. Ninguém achará estranho que uma rainha do pornô exponha seus pontos de vista numa publicação mensal (ALMODÓVAR, 2006, p. 16).

Patty se dedica a contar histórias não edificantes de suas amigas de nomes curiosos: Mary von Ética, Ana Conda, Condom e Addy Posa. As descrições dos personagens são todas bizarras, por exemplo: Von Ética há quatro anos não corta as unhas e se limita a fumar, tomar drinques e rir nas festas. "A isso EU chamo reduzir a vida ao essencial" (ALMODÓVAR, 2006, p. 18). A palavra EU é sempre grafada em caixa alta para evidenciar a natureza narcisista da personagem e, com isso, acentuar sua dissonância com os modos de reivindicação tradicionais: "estamos condenadas a trivialidades do tipo nos dedicar à prostituição, ao terrorismo, à criação dos filhos ou a fazer ginástica" (ALMODÓVAR, 2006, p. 18). A atualidade é a capacidade de encenação, atuação e performance. "E EU tenho uma boa dose desta capacidade. Eu sou a atualidade” (ALMODÓVAR, 2006, p. 17).

Enquanto em Fogo nas entranhas (2000) há uma proposta coletiva, mesmo sendo um delírio do corpo enlouquecido, Patty Diphusa (2006) é um elogio à intimidade. Almodóvar se repete e até mesmo o provérbio chinês que utiliza como epígrafe em Fogo nas entranhas aparece em Patty Diphusa de maneira jocosa. Patty insinua que uma pessoa seja japonesa por se esquivar de perguntas, para utilizar o famigerado provérbio: "o demônio caminha em linha reta". Depois ela diz não estar certa se o ditado é chinês ou japonês, inferindo, grosseiramente, que é tudo a mesma coisa.

Sem grandes questões da arte para tratar, Almodóvar parece dizer, como Hegel, que a arte chegou ao seu limite cognitivo como meio de fazer o transporte do ser humano da ignorância para o conhecimento. "O fim da arte é, para Hegel, somente o fim da capacidade da arte de continuar a servir como fonte adequada para a autorreflexão do Espírito" (DANTO, 2014, p. 14). Nesse sentido, Almodóvar, no caminho entre Fogo nas entranhas e Patty Diphusa, parece livre do fardo de produzir uma obra que viabilize a consciência e o debate. E também se livra da necessidade de produzir beleza. Restou, com isso, a individualidade, o egocentrismo, o narcisismo.

\section{From the entrails of MEMory aNd Clichés in Almodóvar's erotic Revolution}

Abstract: In the films of the Spanish filmmaker Pedro Almodóvar there is a conviction that the maintenance of a society requires some unacceptable operation. This is what the 1981 soap opera Fogo nas entranhas intends to show. A way of life that feeds on the vital energy, the repressed sex of its characters and promotes the creation of events that are not located in memory, a type of violence which traditionally is not in the field of female experience: the sexual violence of women against men.

Keywords: Almodóvar. Soap opera. Memory. Repression. Eroticism. 


\section{REFERÊNCIAS}

ALMODÓVAR, P. Fogo nas entranhas. Rio de Janeiro: Dantes, 2000.

ALMODÓVAR, P. Patty Diphusa. Rio de Janeiro: Azougue Editorial, 2006.

BERGSON, H. Matéria e memória. São Paulo: Martins Fontes, 1999.

BHABHA, H. O local da cultura. Belo Horizonte: Ed. UFMG, 1998.

BUTLER, J. Problemas de gênero: feminino e subversão da identidade. Rio de Janeiro: Civilização Brasileira, 2017.

CHAUÍ, M. Repressão sexual. São Paulo: Brasiliense, 1984.

DANTO, A. C. O descredenciamento filosófico da arte. Belo Horizonte: Autêntica, 2014.

DELEUZE, G.; PARNET, C. Diálogos. São Paulo: Escuta, 1998.

DESPENTES, V. Teoria King Kong. São Paulo: N-1 Edições, 2016.

DONALD, J. Liberdade bem regulada. In: COHEN, J. J. A pedagogia dos monstros. Belo Horizonte: Autêntica, 2000.

FOUCAULT, M. A história da sexualidade: o uso dos prazeres. Rio de Janeiro: Graal, 1998. v. 2.

FOUCAULT, M. Microfisica do poder. Rio de Janeiro: Edições Graal, 1984.

FREUD, S. O mal-estar na civilização. Rio de Janeiro: Imago, 1997.

FREUD, S. O estranho. In: FREUD, S. Obras psicológicas completas de Sigmund Freud. Rio de Janeiro: Imago, 1988. v. XVII.

FRIEDAN, B. Mistica feminina. Rio de Janeiro: Vozes, 1971.

GIL, J. Metafenomenologia da monstruosidade: o devir-monstro. In: COHEN, J. J. A pedagogia dos monstros. Belo Horizonte: Autêntica, 2000.

GUATTARI, F. Caosmose: um novo paradigma estético. São Paulo: Editora 34, 2012.

KEHL, M. R. Ressentimento. São Paulo: Casa do Psicólogo, 2015.

MACHADO, R. Deleuze, a arte e a filosofia. Rio de Janeiro: Jorge Zahar, 2009.

NIETZSCHE, F. A genealogia da moral. Lisboa: Guimarães Editores, 1992.

PARENTE, A. O virtual e o hipertextual. Rio de Janeiro: Pazulin, 1999.

POLIMENI, C. Pedro Almodóvar y el kitsch español. Madri: Campo de Ideias, 2004.

STRAUSS, F. Conversas com Almodóvar. Rio de Janeiro: Jorge Zahar, 2008. 